\title{
Photobacterium damselae infection in yellow tail surgeon (zebrasoma xanthurum) of Red Sea at Hurghada, Egypt
}

\author{
Mahmoud Hashem \\ Fish Diseasese, Dept., Fac. Vet. Med., Assuit Univ., Egypt
}

Email address:

dm4467201@yahoo.com

To cite this article:

Mahmoud Hashem. Photobacterium damselae Infection in Yellow Tail Surgeon (zebrasoma xanthurum) of Red Sea at Hurghada, Egypt. American Journal of Life Sciences. Special Issue: Marine Biology. Vol. 3, No. 1-1, 2015, pp. 10-14. doi: 10.11648/j.ajls.s.2015030101.13

\begin{abstract}
Photobacterium damselae causes photobacteriosis of marine ornamental yellow tail surgeon (zebrasoma xanthurum) the disease appeared and spread rapidly in yellow tail surgeon in the indoor aquarium of National Institute of Oceanography and Fisheries (NIOF) at Hurghada (Egypt). The pathogen was isolated from skin lesions in the body, and internal organs namely liver,spleen and kidney of clinically diseased and moribund fish using tryptic soy agar and thio-sulphate citrate bile salt sucrose agar plates. Lethargic, off food, hemorrhagic spots on skin, skin depigmentation, and fin rot were the main clinical signs appeared on the naturally infected fish. All isolates of the bacterium constituted a homogeneous phenotypic group and were identified by morphological characterization, biochemical tests and API20E as Photobacterium damselae. The isolated strain was sensitive to Sulfamethoxazole Gentamycin, and Streptomycin.
\end{abstract}

Keywords: Photobacterium damselae, Photobacteriosis, zebrasoma xanthurum, Streptomycin, API20E

\section{Introduction}

Pasteurellosis or photobacteriosis is a fish disease that causes enormous losses in fish aquaculture production worldwide (Kusuda \& Salati 1993, Romalde \& Magariiios 1997). The causative agent of fish pasteurellosis is the Gramnegative halophilic bacterium Photobacterium damselae subsp, piscicida, it was subsequently transferred to the genus Photobacterium according to the phenotypic data (Smith et al., 1991), and further support was obtained from the phylogenetic analysis carried by Ruimy et al. (1994). According to the basis of phylogenetic analysis of $16 \mathrm{~S}$ rDNA sequences and DNA relatedness the fish pathogen Pasteurella piscicida, which causes pasteurellosis in several fish species, was found to be a member of Photobacterium damselae (Gauthier et al., 1995). Photobacterium damselae was initially isolated from white perch and striped bass in the Chesapeake Bay, USA in 1963 (Snieszko et al.,1964). In 1969,the pathogen caused great economic losses in cultured yellowtail in Japan (Seriola quinqueradiata) (Kubota et al., 1970; Kusuda and Yamaoka, 1972), ayu (Plecoglossus altivelis) (Kusuda and Miura, 1972), black sea bream (Mylio macrocephalus) (Muroga et al., 1977; Ohnishi et al., 1982), red sea bream (Yasunaga et al., 1983), oval file fish (Navodan modestus) (Yasunaga et al., 1984), and red grouper
(Epinephelus okaara) (Ueki et al., 1990). Moreover, this disease has been reported in the snake-head fish (Channa maculata) in Taiwan (Tung et al.,1985). In Europe and the Mediterranean, photobacterium was first isolated from the juvenile gilthead sea bream (Sparus aurata) in the northwest of Spain in 1991 (Toranzo et al., 1991).in Egypt photobacterium damsel was isolated from Mugil cephalus, Mugil capito and Nile tilapia (Reyad and Salah,2008). The clinical findings of the diseased fishes were haemorrhagic at fins bases, peripheral site of genital pore, and bilateral surface of the abdomen. Additionally, we discovered whitishmucus gills, edema of the intestines, and multi-focal whitetubercles in infected fishes during gross examination.( Liu et al.,2011). Anorexia with darkening of the skin as well as focused necrosis of the gills are the only external clinical signs often observed in some cases( Barber and Swygert,2000). Affected fish had gas distended swim bladders, anaemia, and the intestines were diffusely distended with a clear, pale yellowish fluid. Livers were mottled tan and green in a zonal pattern(Stephens et al.,2006).The experimentally infected fishes showed skin darkening and hemorrhaging of the caudal fin and operculum. Internally, whitish pin-sized nodules were seen in the liver, spleen and kidneys with 40 and 30\% mortality among Oreochromis niloticus and Cyprinus carpio respectively (Reyad and Salah, 2008). In this study we found that photobacteriosis was able 
to cause serious infection, even death, in the yellow tail surgeon fish, (zebrasoma xanthurum) in indoor aquarium of National Institute of Oceanography and Fisheries at Hurghada Egypt. Morphological and biochemical identification, antibiotic sensitivity test and virulence of the isolates are described.

\section{Materials and Methods}

\subsection{Fish}

Thirty clinically diseased and moribund yellow tail surgeon fish (zebrasoma xanthurum) were collected from the indoor aquaria of The National Institute of Oceanography and Fisheries (NIOF) at Hurghada and subjected to clinical examination and bacteriological isolation according to Liu et al.,2011.

\subsection{Water Samples}

Water samples were collected from the investigated indoor aquarium and the red sea (control sample) in dark brown clean and dry bottles. Water temperature and $\mathrm{pH}$ were determined by thermometer and digital combo $\mathrm{pH}$ meter (HI 98127 (pHep 4) -Hanna instruments Inc., USA), total ammonia was determined and dissolved oxygen (DO) concentration were measured using a digital dissolved oxygen meter (HI 9142 - Hanna instruments Inc., USA).

\subsection{Bacterial Isolation and Characterization}

Samples for bacterial isolation were taken from skin ulcers, liver, spleen and kidney of moribund and clinically diseased yellow tail surgeon fish, (zebrasoma xanthurum) and cultured on plates of tryptone soya agar (Oxoid) supplemented with $1.5 \%(\mathrm{w} / \mathrm{v})$ sodium chloride (TNA) . The inoculated plates were incubated at $28^{\circ} \mathrm{C}$ for up to $72 \mathrm{hrs}$.The suspected P.damselae colonies were isolated, purified using thiosulphate citrate bile salt sucrose agar (TCBS, Difco) and characterized and identified according to standard morphological, physiological, biochemical method and Commercial miniaturized API 20E galleries (BioMerieux) (Gauthier et al., 1995; Abbasi et al., 2010; Liu et al.,2011)

\subsection{Antibiotic Sensitivity Assay}

The bacteria were grown on TSA at $28^{\circ} \mathrm{C}$ for $24 \mathrm{~h}$. Then the bacteria were suspended in sterile phosphate buffered saline [PBS] and diluted as the MacFarland No. 0.5 standard solution tube $(0.5 \mathrm{~mL} \mathrm{BaSO} 4+99.5 \mathrm{~mL} 0.36 \mathrm{~N} \mathrm{HCl})$, about $1 \times 107 \mathrm{CFU} / \mathrm{mL}$. The bacterial suspension $(0.1 \mathrm{ml})$ was spread onto Mueller-Hinton agar (Difco) and antibiotic discs then added as described by Koneman et al. (1988). and the following antibiotics streptomycin, chlormphenicol, oxytetracycline, oxolinic acid, ciprofloxacin, getamicin, Ampicillin, sulfamethoxazole and kanamycin, were used (Oxoid). The tested plates were incubated at $28^{\circ} \mathrm{C}$ for $18 \mathrm{~h}$. The results were then interpreted and recorded according to Koneman et al.,(1988).

\subsection{Fish Pathogenicity Experiments}

Twenty (20) yellow tail surgeon (zebrasoma xanthurum) fish were acclimated for one week in the indoor aquarium and subdivided into two equal groups each of 10 fish (weighing $110 \pm 10 \mathrm{~g}$. each) and held in a tank (100 liter) for testing. Each fish in the first group received intraperitoneal (i.p.) injections with0.1 mL/fish of bacterial suspension to achieve doses of $10^{6}$ cells fish $^{-1}$ (Toranzo et al. 1983). The second group inoculated with sterile PBS by i.p. served as the parallel control. The clinical signs and mortalities were monitored and recorded daily for 14 days after the shots. Reisolation and identification of the bacteria from the inoculated fish was also performed.

\section{Results}

\subsection{Clinical Signs}

The clinical signs of the diseased zebrasoma xanthurum fish were lethargic, off food with depigmentation of the skin of the infected fish. Skin hemorrhagic spots and fin rot were also recorded (Figure -1 and2). The main post mortem lesions were pale yellowish fluid in the abdominal cavity, the livers were mottled in a zonal pattern with presence of small nodules also congestion and adhesions of the internal organ was recorded (Figure -3 and4). The recorded mortality among the diseased fish was $60 \%$..

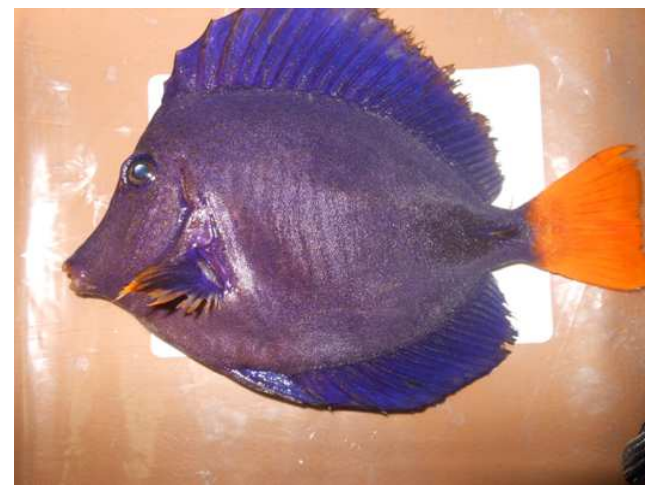

Figure (1). Yellow tail surgeon (zebrasoma xanthurum) fish showed Skin hemorrhagic spots and fin rot.

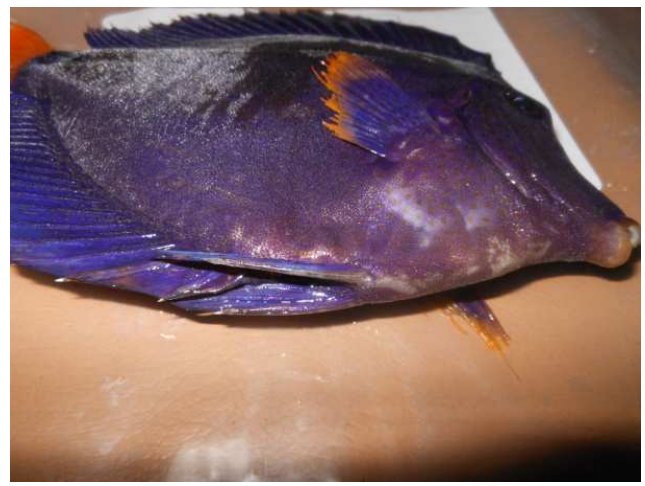

Figure (2). Yellow tail surgeon (zebrasoma xanthurum) fish showed Skin depigmentation and fins rot. 


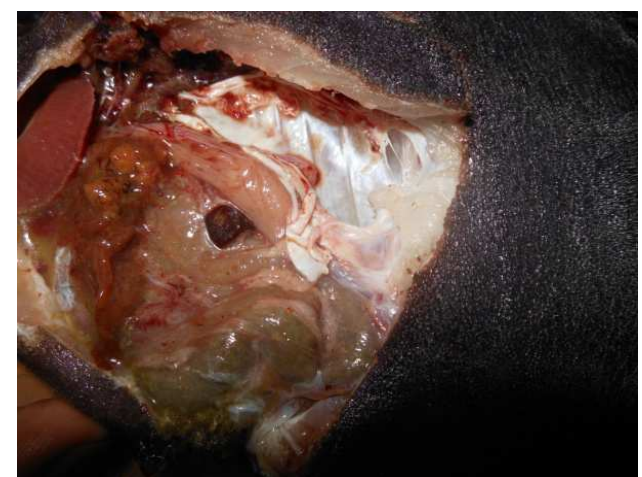

Figure (3). Yellow tail surgeon fish show presence of liver nodules also congestion and adhesions of internal organs

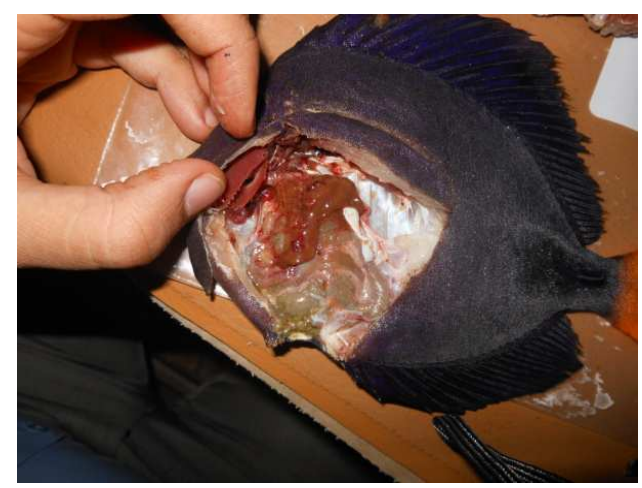

Figure (4). Yellow tail surgeon fish showed liver were mottled in a zonal pattern.

\subsection{Water Quality}

The results of this study revealed elevation of ammonia and $\mathrm{pH}$ values while the dissolved oxygen was decreased in the water samples of indoor aquarium, table (1).

Table 1. Water quality criteria.

\begin{tabular}{llll}
\hline Item & Unit & Tested sample & Control sample \\
\hline Water temperature & ${ }^{\circ} \mathrm{C}$ & 26 & 25 \\
pH values & - & 8 & 7.5 \\
Dissolved oxygen & $\mathrm{mg} \mathrm{L}^{-1}$ & 3.1 & 5.5 \\
total ammonia & $\mathrm{mg} \mathrm{L}^{-1}$ & 0.0054 & 0.00038 \\
\hline
\end{tabular}

\subsection{Bacterial Characterization}

Nine bacterial isolates were isolated from skin lesions, liver, kidney, and spleen. These colonies of presumptive Photobacterium damselae were rounded viscous, regular shiny-grey-yellow in color. The biochemical and physiological characteristics of all the isolates were similar and allowed the presumed identification of the bacteria as Photobacterium damselae. In fact the staining characteristics of our pleomorphic rod-shape isolate were Gram-negative with bipolar staining, non-motile, oxidase and catalase positive. They were negative in Vogues-Proskauer and lysine decarboxylase tests but positive in arginine dehydrolase, and urease tests. All bacterial isolates produced acid from carbohydrates fermentation test (D-glucose and D-mannitol) but no gas produced. However, no acid was produced from other carbohydrates such as D-lactose, D- Arabinose, D- raffinose, and L-rhamnose (Table 2). All bacterial isolates grew well at $25-35^{\circ} \mathrm{C}$ on TCBS agar with green colonies and all bacterial isolates grew well in 1.5-6 \% (w/v) sodium chloride but not in $0 \%$ and $8 \%$, respectively.

Table 2. Results of the biochemical characterization of the Photobacterium damselae isolates

\begin{tabular}{llll}
\hline Tests & Result & Tests & Result \\
\hline Colony shape & Round & Colony colour & Viscous yellow \\
Gram stain & -ve rods & Motility & + ve \\
Cytochrome oxidase & + ve & Catalase & + ve \\
Growth in $0 \% \mathrm{NaCl}$ & - & Growth in $1.5 \%$ & + \\
$6 \% \mathrm{NaCl}$ & & NaCl & \\
nitrate & + & $8 \% \mathrm{NaCl}$ & - \\
API20E & + & $0 / 129$ disk & + \\
ONPG & & & \\
ADH & - & GEL & - \\
LDC & + & Glucose & + \\
ODC & + & Manitol & + \\
CIT & - & Inositol & - \\
H2S & + & Sorbitol & - \\
URE & - & Rhaminose & - \\
TDA & + & Sucrose & v \\
IND & - & Malonate & - \\
VP & - & Adonitol & - \\
Raffinose & + & Arabinose & - \\
Xylose & - & Salicin & - \\
\hline
\end{tabular}

$\mathrm{ODC}=$ ornithine decarboxylase, $\mathrm{LDC}=$ lysine decarboxylase, $\mathrm{ADH}=$ arginine dihydrolase, IND = indole, $\mathrm{CIT}=$ citrate, $\mathrm{URE}=$ urea hydrolysis, $\mathrm{VP}=$ Voges-Proskauer, TDA =tryptophane deaminase, GEL = gelatin hydrolysis, ONPG= Ortho -nitrophenyl b-d-galactopyranoside, $\mathrm{H} 2 \mathrm{~S}=$ hydrogen sulfide production.

\subsection{Antibiotic Sensitivity Assay}

The antimicrobial sensitivity test revealed that the isolated strain was sensitive to Sulfamethoxazole Gentamycin, and Streptomycin. Controversially, it was resistant to Ampicillin, Ciprofloxacin, Chloramphenicol, Kanamycin, Oxytetracycline And Oxolinic acid (table 3).

Table 3. Sensitivity of Photobacterium damselae isolates to various antibiotics.

\begin{tabular}{ll}
\hline Antibiotics & Result \\
\hline Ciprofloxacin & $\mathrm{R}$ \\
Chloramphenicol & $\mathrm{R}$ \\
Streptomycin & $\mathrm{S}$ \\
Kanamycin & $\mathrm{R}$ \\
Oxytetracycline & $\mathrm{R}$ \\
oxolinic acid & $\mathrm{R}$ \\
Ampicillin & $\mathrm{R}$ \\
getamicin, & $\mathrm{S}$ \\
sulfamethoxazole & $\mathrm{S}$ \\
\hline
\end{tabular}

$\mathrm{S}=$ sensitive $\mathrm{R}=$ Resistant

\subsection{Fish Pathogenicity Experiments}

The virulence assays with Photobacterium damselae isolates demonstrated that the experimentally infected yellow tail surgeon fish showed lesions similar to those of naturally infected fish, lethargic, off food, with depigmentation of the 
skin and, hemorrhagic spots on the skin. The observed PM lesions revealed the presence of congestion of the visceral organs and ascitis. By the end of observation time (14 days) the cumulative mortality of the experimentally infected fish reached $70 \%$. Photobacterium damselae was re-isolated in pure culture from the experimentally infected fish.

\section{Discussion}

Photobacteriosis is caused by the halophilic bacterium Photobacterium damselae subsp. piscicida (formerly Pasteurella piscicida). The detection of Photobacterium damselae infection in yellow tail surgeon in the present condition favoring the establishment of photobacteriosis by this highly pathogenic halophilic organism. This pathogen has proven to be detrimental to wild and aquarium fishes, and is responsible for severe losses of cultured yellowtail juveniles (Kusuda and Yamaoka, 1972), gilthead sea bream outbreak in northwestern Spain in 1990 (Toranzo et al., 1991) , Ayu, Red sea bream, Black sea bream and Red grouper in Japan (Acosta et al., 2006; do Vale et al., 2005). The clinical signs of Photobacterium damselae infection in yellow tail surgeon fish were lethargic, off food with depigmentation of the skin of the infected fish, skin hemorrhagic spots and fin rot. Similar observations were noticed by Stephens et al., (2006), Reyad and Salah, (2008) and Liu et al.,(2011). The clinical signs of photobacteriosis were noticed on the wild investigated yellow tail surgeon within few days after fishing and rearing in the indoor aquarium. The onset of the disease may be resulted from the suppression of the fish immune system due to increased ammonia and $\mathrm{pH}$ level and decreased dissolved oxygen in addition to the over crowdedness in the indoor aquarium. This explenation was supported by Bullock et al.,(1986 )and Suomalainen et al., (2005). The Postmortem lesions revealed presence of pale yellowish fluid in the abdominal cavity, livers were mottled white and green in a zonal pattern also congestion and adhesions of internal viscera. Similar postmortem lesions were recorded by agreement with the findings of Belen et al., (1992), Stephens et al.(,2006), Reyad and Salah,2008 and Labella et al.,( 2011). The Nine bacterial isolates from naturally infected fish during mortality episodes were identified as Photobacterium damselae by the colony characters, cell morphology, gram stain and biochemical reactions including the API20E tests. This finding was in agreement with the result of Toranzo et al., (1991), Nicky (2004), Reyad and Salah (,2008)and Liu et al.,(2011). The antibiotic sensitivity test of Photobacterium damselae showed that the isolated strain was sensitive to Sulfamethoxazole Gentamycin, and Streptomycin. Controversially, it was resistant to Ampicillin, Ciprofloxacin, Chloramphenicol Kanamycin, Oxytetracycline And Oxolinic acid. As such, the study mor or less ingreement with Labella et al.,(2011) Reyad and Salah(,2008).The high resistance of the recovered photobacteria isolates to most commonly used antimicrobial drugs proven the importance of antimicrobial sensitivity test application before the therapy (Stephens et al.,
2006).The experimentally infected yellow tail surgeon fish showed lesions similar to those of naturally infected fishes such lethargic, off food, with depigmentation of the skin and, hemorrhagic spots on the skin. associated with $70 \%$ mortality and similar clinical signs were reported by Toranzo et al., (1983) Reyad and Salah, (2008). The pathogenicity of $P$. damselae may be attributed to the extracellular product mainly damselysin, a thermolabile extracellular cytotoxin of $69 \mathrm{kDa}$, which is a phospholipase $\mathrm{D}$ active against the sphingomyelin of the sheep erythrocyte membrane and has haemolytic activity against several erythrocyte types, including fish (Kothary \& Kreger, 1985; Cutter \& Kreger, 1990 and Kreger et al., 1987) . In conclusion Photobacterium damselae is the causes zebrasoma xanthurum mortality and its importance as a pathogen in salt water aquaculture is being increasingly recognized. Therefore it may become necessary to conduct further studies toward vaccination and molecular characterization.

\section{References}

[1] Abbasi,F.M., Ahmad, H., Perveen, F., Inamullah, Sajid, M., Brar D.S., 2010. Assesment of genomic relationship between Oryza sativa and Oryza australiensis. Afr. J. Biotechnol., 9(12): 1312-1316.

[2] Acosta, F., Ellis, A.E., Vivas, J., Padilla, D., Acosta, B., Deniz, S., Bravo ,J., Real, F.,2006. Complement consumption by Photobacterium damselae subsp. piscicida in seabream, red porgy and sea bass normal and immune serum. Effect of the capsule on the bactericidal effect. Fish Shellfish Immunol., 20: 709-717.

[3] Barber, G. R., Swygert, J. S., 2000. Necrotizing fasciitis due to Photobacterium damsela in a man lashed by a stingray. $N$. Engl. J. Med. 342: 824-1056

[4] Belen ,F., Jens,L., Bent, N., Juan, L.B. , Elicia, E. T., 1992. Characterization of Vibrio damsela strains isolated from turbot Scophthalmus maximus in Spain. Dis. aquat. Org. 12:155-166

[5] Bullock, G.L., Hsu, T.C., Shotts, E.B., 1986. Columnaris disease of salmonids.

[6] U.S. Fish and Wildlife Service, Fish Disease Leaflet, 72, 9 pp.

[7] Cutter, D.L. \& Kreger, A.S.,1990. Cloning and expression of the damselysin gene from Vibrio damsela. Infection and Immunity 58: 266-268.

[8] do Vale A., Silva, M.T., dos Santos, N.M., Nascimento, D.S., Reis-Rodrigues, P., Costa-Ramos, C., Ellis, A.E., Azevedo, J.E., 2005. AIP56, a novel plasmid-encoded virulence factor of Photobacterium damselae subsp. piscicida with apoptogenic activity against sea bass macrophages and neutrophils. Mol. Microbiol., 58: 1025-1038.

[9] Gauthier, G., Lafay, B., Ruimy, R., Breittmayer, V., Nicolas, J.L., Gauthier, M. \& Christen, R. ,1995. Small-subunit rRNA sequences and whole DNA relatedness concur for the reassignment of Pasteurella piscicida (Snieszko et al.) Janssen and Surgalla to the genus Photobacterium as Photobacterium damsela subsp. piscicida comb. nov. International Journal of Systematic Bacteriology 45: 139-144. 
[10] Koneman, E.W., Allen, S.D., Dowell, V.R., Janda, W.M., Sommers, H.M., Winn, W.C., 1988. Diagnostic Microbiology, 3rd edu. Philadelphia: J. B. Lippincott.

[11] Kothary, M.H. \& Kreger, A.S., 1985. Purification and characterization of an extracellular cytolysin produced by Vibrio damsela. Infection and Immunity 49: 25-31.

[12] Kreger,A.S.,Bernheimer, A.W., Etkin, L.A. \& Daniel, L.W. ,1987.Phospholipase D activity of Vibrio damsela cytolysin and its interaction with sheep erythrocytes. Infection and Immunity 55: 3209-3212.

[13] Kubota, S., Kimura, M., Egusa, S., 1970. Studies on 'bacterial tuberculoidosis' in cultured yellowtail. I. Symptomatology and histopathology. Fish Pathol., 4: 111-118.

[14] Kusuda, R., Miura, W., 1972. Characterization of Pasteurella $s p$. pathogenic for pond cultured ayu. Fish Pathol., 7: 51-57.

[15] Kusuda, R., Salati, F., 1993. Major bacterial diseases affecting mariculture in Japan. Annu Rev Fish Dis 3:69-85.

[16] Kusuda,R., Yamaoka.M.,1972. Etiological studies on bacterial pseudotuberculosis in cultured yellowtail with Pasteurella piscicida as the causative agent. I. On the morphological and biochemical properties. Bull Jpn Soc Sci Fish 38: 1325-1332.

[17] Labella, A., Berbel, C., Manchado, M. ,Castro, D., Borrego, J.J., 2011. Photobacterium damselae subsp. damselae, an Emerging Pathogen Affecting New Cultured Marine Fish Species in Southern Spain, Recent Advances in Fish Farms, Dr. Faruk Aral (Ed.), ISBN: 978-953-307-759-8, InTech.

[18] Liu P.C., Cheng, C.F., Chang, C.H., Lin,S.L.,2011.Highly virulent Photobacterium damselae subsp. piscicida isolated from Taiwan paradise fish, Macropodus opercularis (L.), in Taiwan.`African Journal of Microbiology Research . 5(15: 2107-2113.

[19] Muroga, K., Sugiyama, T., Ueki, N. 1977. Pasteurellosis in cultured black sea bream Mylio macrocephalus. J. Faculty Fisheries Anim. Husb., Hiroshima University 16: 17-21.

[20] Nicky, B. B., 2004. Bacteria from Fish and Other Aquatic Animals ,CABI :Publishing CAB International Wallingford Oxfordshire OX10 8DE.UK., 357.

[21] Ohnishi, K., Watanabe, K., Jo, Y., 1982. Pasteurella infection in young black seabream. Fish Pathol., 16: 207-210.

[22] Romalde, J.L., Magarinos ,B.,1997) Immunization with bacterial antigens: pasteurellosis. In: Gudding R. Lillehaug A, Midtling PJ, Brown F (eds) F s hv accinology. Development in Biological Standardlzatlon, Vol90. Karger, Basel, p 167-177.

[23] Ruimy, R., Breittmayer, V., Elbaze, P., Lafay, B., Boussemart,
O., Gauthier, M. \& Christen, R. ,1994. Phylogenetic analysis and assessment of the genera Vibrio, Photobacterium, Aeromonas and Plesiomonas deduced from small subunit rRNA sequences. International Journal of Systematic Bacteriology 44: 416-426.

[24] Reyad, H., and Salah, M. ,2008.Photobacteriosis in some wild and cultured freshwater fishes in Egypt .International Symposium on Tilapia in Aquaculture $2008: 1121-1128$

[25] Smith, S.K., Sutton, D.C., Fuerst, J.A. \& Reichelt, J.L., 1991. Evaluation of the genus Listonella and reassignment of Listonella damselae (Love et al.) MacDonell and Colwell to the genus Photobacterium as Photobacterium damselae comb. nov. with an emended description. International Journal of Systematic Bacteriology 41: 529-534..

[26] Snieszko, S..F, Bullock, G.L., Hollis E, Boone .J.G., 1964. Pasteurella species from an epizootic of white perch (Roccus americanus) in Chesapeake Bay tidewater areas. J. Bacteriol., 88: 1814-1815.

[27] Stephens, F.J., Raidal, S.R., Buller, N., Jones, B. 2006. Infection with Photobacterium damselae subspecies damselae and Vibrio harveyi in snapper, Pagrus auratus with bloat. Aust Vet J. 2006 May;84(5):173-7.

[28] Suomalainen,L.R., Tiirola, M., Valtonen, E.T., 2005. Influence of rearing conditions on Flavobacterium columnaris infection of rainbow trout, Oncorhynchus mykiss (Walbaum). Journal of Fish Diseases, 28(5), 271-27.

[29] Toranzo, A. E., Barja, J. L., Potter, S. A., Colwell, R. R., Hetrick,F. M, Crosa, J. H. ,1983.. Molecular factors associated with virulence of marine vibrios isolated from striped bass in Chesapeake Bay. Infect. Immun. 39: 1220-1227.

[30] Toranzo, A.E., Barreiro, S., Casal, J.F., Figueras, A., Magariños, B., Barja ,J.L., 1991. Pasteurellosis in cultured gilthead seabream (Sparus aurata): first report in Spain. Aquaculture, 99: 1-15..

[31] Tung, M.C., Tsai, S.S., Ho, L.f., Chen, S.C. ,1985. An acute septicemic infection of Pasteurella organism in pond-cultured Formosa snake-head fish (Channa maculata Lacepede) in Taiwan. Fish Pathol., 20: 143-148.

[32] Ueki N., Kayano ,Y., Muroga, K., 1990. Pasteurella piscicida in juvenile red grouper. Fish Pathol., 25: 43-44.

[33] Yasunaga, N., Hatai, K., Tsukahara, J., 1983. Pasteurella piscicida from an epizootic of cultured red sea bream. Fish Pathol., 18: 107-110.

[34] Yasunaga, N., Yasumoto, S., Hirakawa, E., Tsukahara, J., 1984. On a massive mortality of oval file fish (Navodan modestus) caused by Pasteurella piscicida. Fish Pathol., 19: 51-55. 